\title{
O entre-lugar do narrador e do tempo em A História da Sua Vida e A Chegada - uma análise comparativa
}

\author{
Victoria Barros ${ }^{\mathrm{i}}$ \\ Alice Crivano ${ }^{\mathrm{ii}}$ \\ Marinês Lima Cardoso ${ }^{\mathrm{iii}}$
}

\section{RESUMO}

A partir de uma metodologia comparativa entre o conto A história da sua vida e sua versão cinematográfica, A chegada, o objetivo deste trabalho é demonstrar como os elementos narrativos, narrador e tempo, funcionam em cada um dos gêneros em questão. A análise contempla, à luz da teoria, exemplos e recursos utilizados, levando em conta aspectos referentes à tradução intersemiótica. Após o estudo, foram evidenciadas as técnicas empregadas para criar/manter os mesmos efeitos de sentido e o suscitado engajamento do leitor/espectador e destacados pontos divergentes e convergentes entre as duas versões.

Palavras-chave: Tradução Intersemiótica; Cinema; Narratologia; Temporalidade.

\footnotetext{
${ }^{\text {i }}$ Possui licenciatura e bacharelado em Letras - Língua Portuguesa e Italiana - pela Universidade do Estado do Rio de Janeiro (UERJ - 2018). Possui experiencia de pesquisa acadêmica na área de Literatura, com ênfase em Literatura Comparada através da aplicação dos princípios da psicanálise junguiana e do monomito campbelliano. É mestranda em Literaturada Comparada pela Universidade do Estado do Rio de Janeiro (UERJ).
}

ORCID: https://orcid.org/0000-0002-5511-5898 | tradvictoriabarros@ gmail.com

ii Graduada na habilitação Português/ Italiano pela UERJ. Atualmente, mestranda em Teoria da Literatura e Literatura Comparada e graduanda na habilitação Português /Espanhol pela mesma universidade. Especialista em Tradução - Língua Italiana, pela UERJ. Realizou estágio de iniciação à docência sob a orientação da Profa. Dra. Carmem Praxedes, intitulado "Implementação da Licenciatura em Letras habilitação Português e Italiano"; e sob a orientação do Prof. Dr. Alcebíades Martins, os estágios de iniciação à docência nos projetos "Monitoria de Língua Italiana"; e "Licom: Línguas para a Comunidade", como professora de italiano e como estagiária de estágio interno complementar no projeto "Escritório Modelo de Tradução Ana Cristina César". Possui interesses nas áreas de Línguas Italiana e Espanhola, suas respectivas literaturas, Língua Portuguesa, Literaturas, Teoria da Literatura, Tradução e Literatura Comparada. Durante o estágio no Escritório Modelo de Tradução, traduziu três poesias italianas de Sérgio Garau, grande campeão nos "Poestry Slam", que foram para a Flupp. Ainda serão publicados dois livros de Marco Fojanini, um de contos e outro de poesias traduzidas conjuntamente com outros da equipe da Empresa Sintagma Traduções. Outros livros revisados já foram publicados.

ORCID: https://orcid.org/0000-0002-9171-7968 | alice.crivano@ gmail.com

iii É Professora Adjunta do Departamento de Letras Neolatinas - Setor de Língua e Literatura da Universidade do Estado do Rio de Janeiro - UERJ. Possui Doutorado (2010) e Mestrado (2005) em Letras Neolatinas, opção Literatura Italiana, pela Universidade Federal do Rio de Janeiro e Bacharelado (2001) e Licenciatura em Português-Italiano também pela Universidade Federal do Rio de Janeiro. Tem interesse pelas áreas de Literatura Italiana e tradução ou adaptação cinematográfica.

http://orcid.org/0000-0002-9687-7549| marinesrj@yahoo.com.br 


\begin{abstract}
From a comparative methodology between the short story Story of your life and its cinematographic version, Arrival, this work aims to demonstrate how the narrative elements (narrator and time) function in each of the studied genres. The analysis contemplates, in the light of theory, examples and resources employed, considering aspects that refer to the intersemiotic translation. Subsequently, it was emphasized the techniques used to create/maintain the same effect of meaning and to generate the engagement of the reader/viewer. It was accentuated the converging and diverging items between the two versions as well.
\end{abstract}

Keywords: Intersemiotic Translation; Film; Narratology; Temporality.

\title{
INTRODUÇÃO
}

O presente trabalho contempla uma análise comparativa pautada no tempo narrativo e na figura do narrador entre o conto de ficção científica "A história da sua vida" e sua adaptação cinematográfica, intitulada "A chegada". O conto é integrante do livro homônimo, o qual abriga um compilado de contos premiados, lançado em novembro de 2016, cujo autor é Ted Chiang. O filme, por sua vez, é dirigido por Denis Villeneuve e estreou também em 2016, sendo bem recebido pela crítica e pelo público, com oito indicações ao prêmio Oscar de 2017, levando a premiação referente ao quesito melhor edição de som.

Para o desenvolvimento deste artigo, serão enfocados os elementos narrativos tempo - seja em sua instância discursiva, seja em sua instância narrativa - e narrador, além de questões relacionadas à tradução intersemiótica. Esta é um elo entre as duas obras contrastadas e figura como parte interlinguística na própria narrativa, ou seja, na interação das línguas humana e alienígena.

O conto apresenta uma protagonista forte e inteligente que tem sua visão de mundo totalmente mudada como consequência de haver aprendido um idioma alienígena muito distinto daqueles falados por humanos. Tanto o conto quanto o filme alicerçam-se na teoria linguística de Sapir-Whorf para demonstrar como essa transformação ocorreu, ou seja, ambos se pautam na relação intrínseca entre a língua e o modo de pensar de seus falantes. A maneira como ocorre a narração da protagonista que 
aprende o novo idioma é o ponto central para o vislumbre de sua nova perspectiva, narração essa que ocorre por meio de diferentes recursos em cada um dos suportes comparados.

\section{A NARRATIVA}

Como anteriormente tratado, o objetivo do presente trabalho é estudar os elementos narrativos de duas obras, por isso, é necessário definir o conceito de narrativa que será utilizado neste trabalho. Com base em Christian Metz, esse conceito pode ser definido por cinco pontos principais: ter um começo e um fim; ser uma sequência com duas temporalidades - a da coisa narrada e a da narração; ser um discurso; ser conscientemente não-real; ser um conjunto de acontecimentos (2004, p. 30-37).

O estudo da narrativa ou narratologia, retomado por Gerard Genette, tem dois possíveis ramos: o modal e o temático. O primeiro se relaciona com as formas de expressão por meio das quais algo é contado, enquanto o segundo se ocupa da história contada, das ações das personagens e das suas relações entre si, por exemplo (1976, p. 83). Faz parte do estudo da narratologia modal a temática da temporalidade, centro de discussão do presente trabalho.

\section{O TEMPO}

Para Benedito Nunes, em "O Tempo na Narrativa", o tempo é um aspecto essencial da narrativa que o preenche com acontecimentos sequenciais e, assim, consegue divisá-lo (1995, p. 05-06). Esta divisão temporal pode ser feita a partir de três planos narrativos: "o da história, do ponto de vista do conteúdo, o do discurso, do ponto de vista da forma de expressão, e o da narrativa, do ponto de vista do ato de narrar" (NUNES, 1995, p. 27, grifo original). É importante ressaltar que o estudo da temporalidade narrativa não pode ser feito a partir de apenas um dos planos, mas, sim, mensurando-o entre os três. Em outras palavras, o tempo deve ser estudado a partir da relação do tempo de narrar e do tempo narrado (1995, p. 30). Segundo Tzvetan Todorov, o tempo de narrar, também chamado de tempo de enunciação ou de escritura, "é a única temporalidade presente na narrativa" (2011, p. 245) enquanto o tempo 
narrado, ou tempo de percepção ou de leitura, "é um tempo irreversível que determina nossa percepção do conjunto" (2011, p. 246). Conforme tais ideias, Nunes afirma que o tempo é linear no que se refere ao discurso, mas é pluridimensional em relação à história (NUNES, 1995, p. 27).

Em contrapartida, Yves Reuter compreende a análise temporal relacionada diretamente à análise espacial, de acordo com as categorias temporais convocadas, o modo de construção do tempo e a sua importância funcional (2002, p. 56).Em outras palavras, Reuter propõe a análise do tempo conforme a sua correspondência ao tempo real, à maneira implícita ou explícita como aparece na narrativa e o seu fator de importância para a mesma. Apesar de compreender o tempo como subordinado ao espaço, Reuter concorda com a perspectiva de Nunes, e consequentemente de Todorov, ao conceber a construção narrativa como realizada "por meio de múltiplas relações entre duas séries temporais: o tempo, real ou fictício, da história contada e o tempo tomado para contá-la (o tempo de sua narração)" (REUTER, 2002, p. 88, grifo nosso).

\section{A NARRAÇÃO}

Além dessa compreensão em comum sobre a realização da construção narrativa, Reuter e Nunes também apresentam as mesmas quatro noções de como analisá-la. São elas: o momento da narração, a velocidade, a frequência e a ordem (REUTER, 2002, p. 88; NUNES, 1995, p. 27-53). Apesar da concordância teórica, é Reuter quem melhor define cada uma das noções acima, portanto, usaremos principalmente as suas definições como maneira de sintetizar as principais ideias.

O momento da narração remete ao instante em que a história é contada (REUTER, 2002, p. 88), ou seja, o tempo narrado (NUNES, 1995, p. 30) e as outras noções são observáveis a partir dessa. A velocidade da narração, por sua vez, diz respeito tanto à duração da história (horas, dias, meses, anos), quanto à duração da narração (linhas, páginas) (REUTER, 2002, p. 89), no entanto, o presente trabalho observará apenas a duração da história tanto na obra literária, quanto na obra cinematográfica. 
A noção de frequência corresponde à presença ou à ausência de igualdade "entre o número de vezes em que um acontecimento se produz na ficção e o número de vezes em que é contado na narração" (REUTER, 2002, p. 90). Assim, demonstra "a capacidade do discurso de 'reproduzir' os acontecimentos recorrentes" (NUNES, 1995, p. 36). A noção de ordem, por sua vez, estabelece a relação entre os acontecimentos narrados e a sua disposição na narrativa (REUTER, 2002, p. 93).

\section{RESUMO DA NARRATIVA ANALISADA}

Neste momento, é oportuno tecer um breve resumo da história a ser analisada. A linguista Louise Banks é chamada pelo governo dos Estados Unidos após a chegada de alienígenas na Terra. Eles não se encontram apenas em solo americano, mas também ao redor do globo. Dessa maneira, todos os governos se unem para desvendar a motivação por trás desta chegada. Louise, ao lado do físico Gary Donnelly, deve buscar compreender este motivo. Ela, por sua formação como linguista, procura entendê-los por meio da língua deles.

Após extenso contato com os heptápodes - assim chamados por terem sete membros simétricos -, Louise começa a compreender melhor a língua deles. Inicialmente, são feitas tentativas de comunicação através da fala, até ela se dar conta da limitação que isso envolve e começa a estudar a comunicação escrita dos alienígenas.

A língua semasiográfica dos heptápodes começa a revelar aspectos interessantes não apenas em termos linguísticos, como também em termos de compreensão do tempo. Gradualmente, Gary começa a obter certo sucesso na compreensão do pensamento físico e matemático dos alienígenas pela resposta positiva dos mesmos ao princípio de Fermat o qual é explicado através de um diagrama sobre um possível trajeto a ser percorrido pela luz. 
Figura 1- Princípio de Fermat

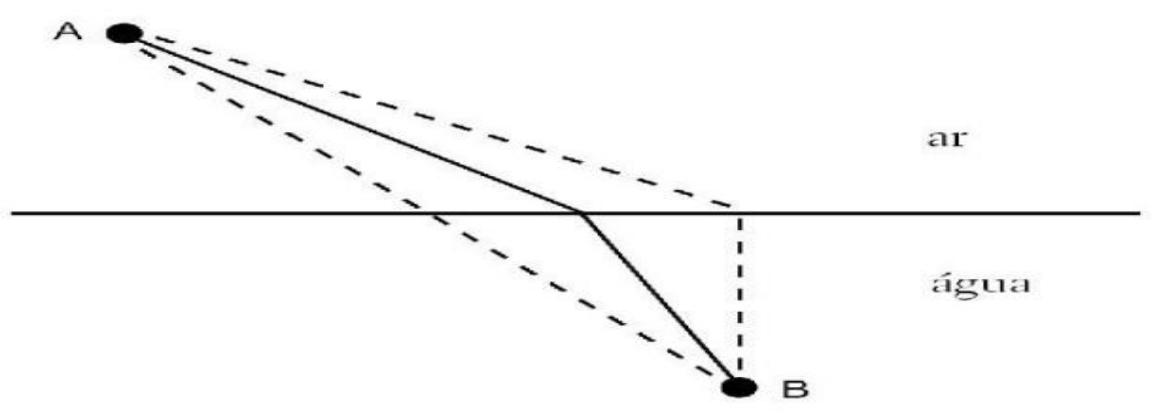

Fonte: CHIANG, 2016, p. 123.

Segundo a explicação do personagem, o caminho traçado pela luz para percorrer do ponto A ao ponto B é menor do que qualquer caminho hipotético imaginado. Sobre o conceito do caminho ser menor, Gary acrescenta que:

- Bem, a palavra "menor" é enganadora. (...) É mais preciso dizer que a luz
sempre segue um caminho extremo, ou um que minimize o tempo levado, ou
um que o maximize. (...) Assim, para ser mais exato, o princípio de Fermat
não é um princípio minimalista; em vez disso, é o que se conhece como
princípio "variacional”. (CHIANG, 2016, p. 124, grifo do autor)

A partir desta constatação física, Louise começa a compreender que a língua dos heptápodes segue o mesmo princípio, refletindo sua concepção de tempo. Ao contrário dos humanos que pensam no tempo como causa e efeito marcado por presente, passado e futuro, os heptápodes pensam nele de maneira fluída, ocorrendo simultaneamente.

Eventualmente, Louise vai se aprimorando cada vez mais na língua heptápode e os militares americanos exigem uma visita aos alienígenas acompanhados dela e de Gary, de maneira que possa haver uma conversa entre os dois lados. Neste momento, em que há uma 'troca de presentes', como os alienígenas falam, os heptápodes vão embora, sem dar as respostas que os terráqueos tanto desejavam. É nesse momento, ao final do conto, que Louise compreende que o presente dado por eles é a capacidade de observar o tempo de maneira não causal, confirmando o princípio teórico de SapirWhorf.

Essa é a narrativa linear e cronológica presente no conto. No entanto, ela é interrompida por fragmentos de distintos momentos temporais e com frequentes saltos para um passado mais distante, intercalados com sequências de tempo progressivas 
cronologicamente. As partes relativas à vida pessoal da protagonista constituem as passagens com maiores saltos que, no conto, passeiam por mais de vinte e cinco anos idade da filha da protagonista ao morrer.

\section{A HISTÓRIA DA SUA VIDA}

O tempo da narrativa no conto e na sua adaptação diferem no que concerne à vida pessoal da protagonista, já que a filha da narradora morre bem mais jovem e devido a uma causa diferente. Por outro lado, as cenas que retratam sua vida profissional são de temporalidade linear, um encadeamento de fatos tal qual o conto. Neste, a simultaneidade, dissertada por Nunes, "só pode representar acontecimentos simultâneos na ordem sucessiva", tendo a tarefa de criar "mediante artifícios ou convenções, a ilusão da simultaneidade", não importando se "o tempo da história se desdobra no espaço (caso mais próximo de simultaneidade no sentido estrito), ou se "o enredo se constitui de múltiplas histórias que se passam em diferentes unidades espaço-temporais" (NUNES, 1995, p. 51). Desta forma, o artifício utilizado para trazer essa ideia de simultaneidade, no conto, é a linguagem utilizada pela narradora-personagem, sobretudo, refletida nos tempos verbais, que expressa no eixo paradigmático sua mudança de perspectiva temporal e de como encarar a vida, consequentemente.

Benedito Nunes sugere uma intemporalidade ficcional em contraste com a temporalidade real. O uso do pretérito perfeito, sob o prisma da realidade, seria uma marcação de "uma ação transcorrida, e, portanto, de acordo com o sistema gramatical", um ato passado, "como fase do próprio tempo" (NUNES, 1995, p. 38). Contudo, no universo ficcional, Nunes cita Harald Weinrich, sendo que este, em um ensaio polêmico, Tempus, esclarece que "os tempos verbais situam o leitor ou o ouvinte no processo comunicacional da linguagem", assim, contrariando os gramáticos que conectaram "os tempos verbais às divisões de tempo" (1995, p. 39).

De fato, uma definição funcional além de uma classificação verbal simplória urge para decifrar os efeitos causados pelo uso de tal categoria gramatical nas passagens narrativas cuja marcação temporal é dúbia. Isto se vê na projeção de uma fala proveniente de um tempo futuro emaranhado a um passado que ainda não se concretizou, como em: "Eu me lembro de quando você tiver 15 anos (...)" (CHIANG, 
2016, p. 126, grifo nosso) e também em "Lembro-me de uma tarde, quando você tiver cinco anos de idade, após voltar para casa depois do jardim de infância” (2016, p. 107, grifo nosso).

O tempo presente pode ser visto como um "quase-passado" (NUNES, 1995, p. 44), "um falso pretérito, que permite efetuar o recuo estético em forma de aproximação dramática" (1995, p. 43) que, ainda segundo este teórico, objetiva o leitor: "o tempo da narrativa não decorre somente das relações entre autor fictício e o texto, mas depende, também, das relações entre o texto e seu destinatário, o leitor" (1995, p. 44).

A inserção do pretérito perfeito, do imperfeito e do mais-que-perfeito indicam um distanciamento, que se está narrando ou contando algo e configuram "uma situação de locução narrativa, ao contrário do presente, do passado composto e do futuro que configuram uma situação de locução discursiva, de comentário" (NUNES, 1995, p. 40, grifo original). Logo, podemos dizer que as cenas de vida pessoal da narradora são contadas, pois há um distanciamento dos fatos. Já as cenas que estão àquelas intercaladas são comentadas, estão em um momento temporal abrangente e complexo, futuro ao mesmo tempo que simultâneo presente-passado, na forma de um desabafo com o leitor ou um monólogo interior ou, ainda, uma conversa imaginária com a filha que não está mais presente. Tais possibilidades não excluem as outras e as duas últimas, assim como a primeira, buscam trazer o leitor mais para perto, ou seja, inseri-lo na história.

Retomando as quatro noções de como analisar as narrativas que nos propomos a seguir, o momento da narração, a velocidade, a frequência e a ordem, definidas por Reuter, fazendo um paralelo com as ideias de Culler, em Teoria Literária: Uma Introdução, ao abordar questões-chave da narrativa: "'quem fala?', 'quem fala para quem?', 'quem fala quando?', 'quem fala que linguagem?', 'quem fala com que autoridade?' e 'quem vê??', (1999, p. 87-92).

O momento da narração pressupõe o que a convenção diz (CULLER, 1999, p. 87): é necessário um narrador, que é quem fala, narra, conta algo. O conto A história da sua vida, como já mencionado, é narrado em dois momentos claramente separados graficamente (asteriscos), pelo uso dos tempos verbais em cada passagem e o conteúdo nelas apresentado. Em ambos os momentos, a narradora é personagem protagonista, figurando uma narração em primeira pessoa, “quem fala?”, a linguista Louise Banks, 
como ilustra o fragmento abaixo. Antecipando a pergunta "quem vê?", a história contada parte do ponto de vista de cada versão dessa narradora que, segundo Culler, pode focalizar o que será contado sob inúmeras variáveis, como a temporal, a distância e a velocidade e, ainda, quanto às limitações de conhecimento (1999, p. 90-92). "Eu os avistei enquanto esperavam no corredor em frente ao meu escritório. Eles formavam uma dupla estranha; (...). Parecia estar avaliando o ambiente com olhar crítico" (CHIANG, 2016, p. 100-101, grifo nosso).

Ainda em relação ao exemplo textual acima, percebe-se que a narração focaliza acontecimentos a partir da época em que ocorreram, contando detalhes fundamentais sobre o que aconteceu nos dias mais significativos, com uma proximidade com o narrado. Assim, apresenta um ponto de vista limitado, dando seu parecer pelo que consegue captar do ambiente, das expressões, das vestimentas e das aparências das pessoas ao seu redor (CULLER, 1999, p. 90-92).

Já em relação ao tempo da narração, percebe-se que é confuso e complexo de ser definido, pois a narradora focaliza toda sua vida - sejam as questões familiares, sejam as profissionais - de um modo integrado e simultâneo, destacando os pontos cruciais, pois o conhecimento da língua heptápode B lhe possibilitou ser onisciente, tomando uma posição de distanciamento do narrado e aproximação com o interlocutor: "Contar isso para você antes não teria feito nenhum bem; durante a maior parte de sua vida, você não vai ter paciência para ouvir uma história tão romântica — brega, você diria. (...) Sei como esta história termina; penso muito nisso. Também penso muito sobre como ela começou (...)” (CHIANG, 2016, p. 100, grifo nosso).

As duas questões “quem fala que linguagem?" e "quem fala com que autoridade?" envolvem a narradora quanto à voz narrativa usada para narrar e à legitimidade de sua fala. Há o que Mikhail Bakhtin (2002, p. 82-83) nomeia como polifonia ou dialogismo na linguagem da narradora nos momentos em que cita exatamente as palavras que seriam ditas pela filha, numa espécie de assimilação futura registrada como um discurso híbrido, uma vez que são as palavras da filha (discurso direto), mas comentadas sob o olhar e interferência da mãe (discurso indireto). A autoridade é reivindicada pela confiança na narradora que é uma estudiosa, pesquisadora renomada e profissional altamente qualificada ao relatar o grande evento que fez sua visão e vida mudarem completamente. Louise pode ser, sob essa óptica, 
uma narradora autorreflexiva, dado que sabe que narra uma história, cujo desfecho conhece muito bem (CULLER, 1999, p. 89).

“Quem fala para quem?” terá como resposta, no conto, o leitor, o que ocorre nas passagens de cunho profissional da narradora. Segundo Culler, "o narrador se dirige a ouvintes que às vezes são subentendidos ou construídos, às vezes explicitamente identificados" (1999, p. 88). Sendo este o caso em que a narradora dialoga com a filha, mas que podemos interpretar como um discurso voltado para si ou também para o leitor, ou, ainda, direcionado para todos esses narratários.

A velocidade refere-se ao tempo de duração da narração em Reuter, respondendo a pergunta “quem fala quando?”, de Culler. O período, cuja narração comporta, é extenso, cinquenta anos, ao passo que é dividido, pois há o tempo em que a narradora vive fisicamente (tempo da realidade, da consciência) e o tempo em que ela é capaz de vislumbrar a totalidade de sua vida (tempo da memória, local de armazenamento da língua alienígena):

\begin{abstract}
Normalmente, o heptápode B afeta apenas minha memória: minha consciência segue rastejando como fazia antes, [...] não há uma combustão real. Contudo, às vezes, tenho vislumbres quando o heptápode $\mathrm{B}$ realmente predomina e vivencio passado e futuro ao mesmo tempo; minha consciência se transforma em uma brasa de meio século de duração queimando fora do tempo. Eu percebo [...] uma simultaneidade. É um período que abrange o resto de minha vida, e a totalidade da sua. (CHIANG, 2016, p. 142-143, grifo nosso)
\end{abstract}

A frequência da narração, então, pode ser vista como a quantidade de vezes em que a narração se intercala entre a realidade da consciência, a da memória e seus respectivos conteúdos, assim como internamente na história em relação à periodicidade das visitas aos heptápodes.

Por fim, no que tange a noção da ordem, pensa-se na importância do enredo conforme Aristóteles que afirma:

[a]ssim, os acontecimentos e o enredo são o objectivo da tragédia e o objectivo [sic] é o mais importante de tudo. [...] [S] um poeta juntar palavras que exprimem carácter e que estão bem elaboradas quanto à elocução e ao pensamento, não realizará a função da tragédia, uma vez que esta, mesmo sendo inferior nesses aspectos, consegue muito mais porque tem enredo e estruturação das acções. De todos estes elementos, aqueles em que a tragédia exerce maior atraç̧ão são as partes do enredo, isto é, as peripécias e os reconhecimentos. [...] O enredo é, pois, o princípio e como que a alma da tragédia e em segundo lugar vêm, então, os caracteres. (2008, p. 49-50) 
Dessa forma, Culler afirma que, "as boas histórias devem ter um começo, meio e fim e que elas dão prazer por causa do ritmo de sua ordenação" (1999, p. 85).

A narradora é a responsável por contar essa "configuração de acontecimentos" (CULLER, 1999, p. 87), o enredo, cujas sequências narrativas apresentam uma coerência sob um ponto de vista macro e micro. O início, o desenvolvimento e a conclusão podem ser percebidos pelo leitor que vai descobrindo como os fragmentos narrativos, separados pelos asteriscos, conectam-se. Esse sinal gráfico separa os trechos de temporalidade narrativa entre a Louise que não sabe ou que está aprendendo a língua heptápode B e a que é capaz de pensar e comunicar-se na mesma língua alienígena. As 'três estrelinhas' funcionam como um fio de coesão do conto como um todo, ordenadamente, mesmo quando a ordem dos acontecimentos narrados não é cronológica.

Aproveitando a alusão do parágrafo precedente, "A história da sua vida” é repleta de simbologia que afirma a ideia cíclica presente em todo o enredo. Apontaremos quatro dados que corroboram essa afirmação. O primeiro é em relação ao início e ao final do conto ser marcado pela mesma cena através da indagação "Você quer fazer um bebê?" (CHIANG, 2016, p. 100; p. 146). O segundo diz respeito à descrição do formato do corpo dos alienígenas, "radialmente simétrico" (2016, p. 104). A disposição de seus olhos em todos os lados (2016, p. 105) apenas confirma isso, já que marca o fato de passado, presente e futuro serem vistos integralmente.

O terceiro apontamento diz respeito ao formato do suporte da escrita como um reflexo de seus falantes heptápodes: "uma tela plana circular" (CHIANG, 2016, p. 110, grifo nosso). Já o quarto e, último, relaciona-se à repetição do número sete, tanto na quantidade de membros do heptápode, quanto na quantidade de seus olhos: "Sete olhos sem pálpebras circundavam o topo do corpo do heptápode" (2016, p. 117). Esse é um dado extremamente significativo, pois o número sete, segundo a numerologia, remete ao perfeito, à totalidade, à busca pela aprendizagem, à conclusão cíclica e à renovação. $\mathrm{O}$ ciclo completo de dias em cada fase da lua são sete; o sete é a soma do três (trindade, parte espiritual, divina, perfeita por ter começo, meio e fim) e do quatro (plano físico formado por quatro elementos, representação do que é terreno). Conclui-se que a presença dos sete membros e dos sete olhos dos alienígenas pode ser interpretada como algo além de uma coincidência. 
Algumas outras imagens reafirmam aspectos realçados no conto, como as duas versões da narradora, as duas divisões de língua dos heptápodes totalmente distintas entre si (a falada e a escrita), sendo que a gramática estudada na língua escrita, segundo observações da narradora, apresenta duas dimensões (CHIANG, 2016, p. 115). Toda essa dualidade incide no paradoxo entre destino e arbítrio, a personagem indaga se, por saber como a filha morreria, foi superprotetora ou se escolheu proteger demais a filha e, por isso, esta se tornou rebelde, sempre querendo se arriscar e se aventurar em situações perigosas.

\section{A CHEGADA}

Julio Plaza defende a necessária busca pelo aperfeiçoamento e pesquisa da denominada tradução intersemiótica que, segundo o teórico, é "concebida como forma de arte e como prática artística na medula da nossa contemporaneidade" (2003, XI). A tradução intersemiótica, também conhecida como transmutação, foi definida por Roman Jakobson "como sendo aquele tipo de tradução que 'consiste na interpretação dos signos verbais por meio de sistemas de signos não verbais', ou 'de um sistema de signos para o outro, por exemplo, da arte verbal para a música, a dança, o cinema ou a pintura', ou vice-versa" (1975, p. 65). Por assim dizer, um ramo da tradução, cujo objeto é a interpretação do signo ou, no caso da narrativa em voga, dos semagramas.

Esse tipo de tradução é evidente dentro da própria narrativa e na mudança do conto para o filme. A tradução intersemiótica, sob o prisma de traduzir a língua heptápode e, consequentemente, o pensamento deles, culminou na assimilação da forma de pensar da cultura alienígena pelos linguistas, gerando um impacto temporal na memória. No processo para a transposição genérica, existem diferenças substanciais observadas, as quais reconstroem ou realizam uma releitura da obra literária (ECO, 2007, p. 385).

Como anteriormente dito, há cinco características fundamentais para descrever uma narrativa, no entanto, o meio no qual ela se manifesta fará com que apresente problemáticas próprias. No caso da relação entre a narrativa cinematográfica e a escrita, as problemáticas dizem respeito à relação entre enunciado e imagem que é fundamentalmente plural, pois "todo plano contém, virtualmente, uma pluralidade de 
enunciados narrativos que se superpõem e que podem se recobrir quando o contexto nos é favorável" (JOST; GAUDREAULT, 2009, p. 36). Assim, analisar um plano de um filme não condiz, necessariamente, com um enunciado de uma página - pode tanto corresponder à página inteira, quanto uma frase apenas.

Outra questão existente nesta relação se encontra na figura do narrador. Na narrativa escrita, ele se apresenta através da evocação e da descrição do mundo narrado e, também, por meio da organização narrativa. Essas duas funções podem ocorrer ao mesmo tempo ou não. Além disso, há, também, as marcas que demonstram a sua presença no discurso, ou seja, os indicadores dêiticos (JOST; GAUDREAULT, 2009, p. 59). Estes acabam por construir um “observador-comentador", conforme diz KerbratOrecchioni (1980, p. 49 apud JOST; GAUDREAULT, 2009, p. 61), tanto em termos de quem profere o discurso, quanto em posicionamento espaço-temporal.

$\mathrm{Na}$ narrativa cinematográfica, por sua vez, essa figura também existe, mas sua presença não é tão notória quanto na narrativa escrita, pois a narrativa cinematográfica é feita de maneira dupla, ou seja, através de imagem em movimento e som. Exatamente por isso que há a possibilidade de enxergar o filme como uma partitura musical por conta da montagem considerada polifônica, ou seja, cada plano se liga ao seguinte não apenas “por uma simples indicação (...), porém por uma progressão simultânea de uma série de linhas múltiplas, cada uma conservando uma ordem de construção independente, sem deixar de estar integrada à ordem de construção da sequência toda" (EISENSTEIN, 1976, p. 256 apud JOST; GAUDREAULT, 2009, p. 44).

Assim, enquanto em uma narrativa escrita é possível identificar o narrador por suas marcas, na narrativa cinematográfica, essas marcas se diluem ao longo dos dois planos - imagem e som -, tornando sua presença mais subjetiva. De fato, "[n]um certo sentido, no cinema, só encontramos utilizações enunciativas dos signos e não propriamente signos enunciativos em si” (JOST; GAUDREAULT, 2009, p. 62).

Então, como observar esse narrador cinematográfico? É necessário primeiro dizer que há dois narradores. "[O] narrador implícito, é aquele que 'fala' cinema por intermédio de imagens e sons; o narrador explícito relata unicamente com palavras" (JOST; GAUDREAULT, 2009, p. 67), portanto, "na qualidade de espectador do filme, tenho tendência de atribuir a narrativa, primeiramente, àquele que o reivindica explicitamente (...)" (2009, p. 67). Assim, o narrador implícito seria aquele que usa da 
narrativa dupla de imagem e som, ou seja, o diretor e todo o aparato técnico por trás do filme, enquanto há a possibilidade de múltiplos narradores explícitos ao longo da obra que são responsáveis pela subnarrativa (2009, p. 68).

$\mathrm{Na}$ tradição cinematográfica, o narrador implícito recebe o nome de "grande imagista" (JOST; GAUDREAULT, 2009, p.39) e sua presença é notória, principalmente, por fazer uso da câmera e da edição. Ele é notado através da câmera, pois é ela

que registra a interpretação do ator de cinema pode, simplesmente pela posição que ela ocupa, ou, ainda, por simples movimentos, intervir e modificar a percepção que o espectador tem da performance dos atores. Ela pode mesmo (...) forçar o olhar do espectador e, nem mais, nem menos, dirigi-lo. (JOST; GAUDREAULT, 2009, p. 40 - 41, grifos originais)

Em outras palavras, a câmera é o instrumento que funde as instâncias de som e imagem em uma coisa só. A expressividade da imagem dada pelo grande imagista é identificada pelos enquadramentos da câmera, os planos utilizados, os ângulos de filmagem e os movimentos da câmera (MARTIN, 2005, p. 44). Exatamente por serem elementos ditados pelo narrador implícito, poder-se-ia dizer que são também elementos que podem identificá-lo.

A edição ou montagem, por sua vez, fornece o contexto para as imagens vistas pelo espectador, de forma que "o sentido da imagem existe em função do contexto fílmico criado pela montagem” (MARTIN, 2005, p. 34). Esta também proporciona “maiores possibilidades de modulação temporal” (JOST; GAUDREAULT, 2009, p. 74), ou seja, é através da edição que o espectador saberá as noções de tempo da narrativa cinematográfica. São estes os sinais que denunciarão a presença de um grande imagista, um narrador invisível, um enunciador, um narrador implícito ou um meganarrador (2009, p. 41).

Em relação à obra "A Chegada", o narrador implícito é o próprio diretor Denis Villeneuve, enquanto os personagens Louise Banks e Ian Donnelley (no conto de Chiang, seu nome é Gary Donnelley) são os narradores explícitos. O filme inicia com um voice-over feito pela atriz Amy Adams, intérprete da personagem Louise Banks, dizendo 'Eu pensava que este era o começo da sua história' e, logo em seguida, há cenas sequenciais dela com um bebê, uma criança e, então, uma adolescente. Quando Louise segura o bebê, ela diz 'Volte para mim' e repete essa frase quando se debruça sob uma 
adolescente sem cabelo e de olhos fechados, provavelmente morta. Todas as cenas são em tom de azul, levando, então, a crer que o bebê, a criança e a adolescente são a mesma pessoa - a filha de Louise - que morre ao final.

Esta conclusão é possível por conta da fotografia - a mesma tonalidade de azul repetida em todas as cenas - e da edição que promove uma colagem, uma seleção de imagens reunidas em uma sequência, de maneira que o espectador forma ideias e extrai significados ao comparar os detalhes visuais de cada tomada (PRAMAGGIORE; WALLIS, 2008, p. 193). Tal comparação pode se dar entre o detalhamento visual de cada tomada com as que vieram anteriormente e as que virão posteriormente (NOLETTO; LOPES, 2018, p. 209), gerando o efeito Kuleshov. Esse efeito de edição demonstra que uma tomada cinematográfica tem seu significado extraído não apenas da tomada em si - ou seja, o que é narrado por ela -, mas, também, pelas associações das tomadas anteriores e posteriores (PRAMAGGIORE; WALLIS, 2008, p. 192). Por conta desta associação entre as cenas anteriores e posteriores com o voice-over de Louise, pode-se chegar à conclusão de que o bebê, a criança e a adolescente são a mesma pessoa, que são a filha da protagonista.

Enquanto no conto, percebe-se o narrador através dos verbos utilizados, no cinema essa instância é percebida através da dupla narrativa - ou seja, do uso de imagem e do som. O voice-over de Louise - ou seja, o som - é o indício de que ela é a narradora. Esta hipótese se reafirma através dos enquadramentos e dos movimentos da câmera que acompanham a personagem por boa parte do filme. Assim, nesta dupla narrativa cinematográfica, pode-se dizer que a narradora explícita e protagonista é Louise Banks, tal qual no conto.

No entanto, diferentemente da obra original, o filme abre espaço para outro narrador, Ian Donnelley. A presença do personagem como narrador se manifesta também através do voice-over, porém, ao contrário de Louise, a técnica utilizada neste momento tem o objetivo de narrar acontecimentos para o espectador de maneira a explicar conceitos linguísticos e de acelerar o tempo da narrativa. Este voice-over é acompanhado por cenas de encontros com os heptápodes e de semagramas que representam palavras de língua inglesa montados de maneira sequencial, reforçando a ideia de aceleração temporal na narrativa. 
O tempo da narrativa parece, a princípio, sequencial e no presente, visto que "[q]ualquer imagem fílmica está, por conseguinte, no presente: o passado perfeito, o imperfeito, eventualmente o futuro, não são senão o produto da nossa apreciação colocada perante os meios de expressão fílmica cujo significado aprendemos a ler" (MARTIN, 2005, p. 30). Portanto, qualquer outro tempo fílmico que se apresente deve ter alguma característica que o apresente como tal. "O futuro é ainda mais inatingível e não o identificamos, a menor que nos seja indicado como tal. O flashback no segundo grau, ou seja “(...) a evocação dos acontecimentos que passaram em relação a um primeiro passado" (MARTIN, 2005, p. 283), pode ser considerado como um equivalente do mais que perfeito (2005, p. 286).

No conto, Ted Chiang intercala as cenas do presente narrativo - encontro com os heptápodes - com o futuro/passado de Louise Banks, marcando este intercalar com sinais gráficos. No filme, por sua vez, as cenas de futuro/passado se apresentam, primeiramente, como lineares para, então, se intercalarem com o presente da narrativa. São sete as cenas de futuro/passado que se interpolam e elas estão estritamente conectadas com o avanço do conhecimento linguístico da protagonista-narradora.

As quatro primeiras cenas ocorrem após o contato com a língua escrita dos heptápodes. A partir de então, conforme Louise vai estudando a língua, outros momentos de flashfoward/flashback ocorrem. A quarta cena ocorre após o seu contato direto com a 'tela' de comunicação alienígena e, até este momento, a relação entre as cenas do futuro/passado de Louise e o momento presente não se explicitam.

A partir da quinta cena, a relação temporal começa a se esclarecer para o espectador. Nessa cena, enquanto Louise olha as fotos da língua escrita, ela volta ao futuro/passado quando sua filha a questiona sobre o termo usado quando os dois lados podem vencer. Louise não sabe e pede que a menina pergunte a seu pai. Assim, termina a cena e ela retorna para o presente. Durante uma conferência, Ian diz o termo 'um jogo de soma diferente de zero' que é aquele questionado pela menina. Imediatamente, Louise volta para o futuro/passado e responde a ela. Essa mesma cena ocorre no conto de Chiang, representando também um ponto de virada na compreensão do leitor.

O sexto flashfoward/flashback ocorre após o contato direto de Louise com os heptápodes - o que nunca chega a acontecer no conto -, momento no qual ela descobre o que era a arma oferecida pelos alienígenas e o seu objetivo. Após a compreensão, a 
personagem volta ao futuro/passado para uma conversa com sua filha. Naquele momento, a menina lhe indaga sobre a separação de seus pais e Louise diz que o pai não tinha o mesmo preparo que ela para a compreensão do tempo e da imprevisível morte da menina. A partir daí, as narrativas temporais se mostram unas para o espectador.

A última cena é o retorno ao futuro/passado de forma voluntária, pois Louise, ao perceber sua arma, usa-a para interromper uma possível crise internacional. Ao fechar seus olhos, ela se coloca, primeiro, na cena em que segura seu livro sobre a língua heptápode e, em seguida, no encontro com o general de segurança chinês. Neste momento, o filme opta por intercalar o presente com o futuro/passado da personagem, enquanto ela fala com o general de segurança nos dois tempos - no presente, ela muda a opinião dele; no futuro/passado, ela encontra as palavras necessárias para essa mudança ocorrer. Assim como no conto, esses momentos acabam por questionar o quanto do livre arbítrio humano existe diante do conhecimento do futuro.

A marcação das diferenças temporais das sequências pode se dar de diversas formas (MARTIN, 2005, p. 280-281). Na obra de Villeneuve, opta-se pela mudança de fotografia, visto que ela possibilita o maior entendimento dos espectadores em relação não apenas ao tempo, mas aos personagens e aos seus humores, às ações por eles realizadas e também ao desenvolvimento de temas (PRAMAGGIORE; WALLIS, 2008, p. 107). Essa mudança aparece nos tons das cenas que transitam entre azul e amarelo.

As cores são divididas em duas faixas principais: cores frias e cores quentes. Tais faixas podem ser associadas a emoções e a elementos cinematográficos específicos. De maneira mais abrangente, “cores 'frias' tendem a sugerir tranquilidade, apatia, serenidade; e, de outro lado, cores quentes tendem a sugerir agressividade, violência e estimulação, excitação" (COSTA, 2011, p. 66 apud OLIVEIRA, 2020, p. 07). No filme analisado, a combinação de cores ocorre de maneira complementar, ou seja, são usadas as "cores opostas no círculo cromático" (OLIVEIRA, 2020, p. 08), visto que azul e amarelo são opostos na paleta. Esta oposição não diz respeito apenas às cores em si, mas, também, aos significados como afirma Costa (2011, p. 66 apud OLIVEIRA, 2020, p. 07) no trecho acima.

Na obra em questão, o azul é usado desde o início do filme e traz ao espectador a sensação de tristeza e luto, principalmente, pela sequência inicial na qual é mostrada a breve história de vida da filha de Louise. Os flashfowards/flashbacks, por sua vez, usam 
do amarelo, denotando alegria - principalmente pelos momentos serem majoritariamente de Louise com sua filha ainda criança. Esta oposição de cores e de emoções ajuda a demarcar momentos diferentes no tempo. O espectador, portanto, é levado a pensar que o luto mostrado pela cor azul se relaciona à alegria perdida mostrada pela cor amarela dos flashfowards/flashbacks. Posteriormente, quando Louise compreende a arma oferecida pelos heptápodes, consequentemente, o espectador compreende que as cenas apresentadas em tonalidade amarela são, na verdade, referentes ao futuro. Assim, o amarelo atua também como uma advertência do que virá. O filme termina, então, com a mesma cena que começou: com a imagem da casa de Louise em tons de azul, ratificando a circularidade que envolve toda a narrativa.

\section{CONCLUSÃO}

O presente trabalho contemplou uma análise comparativa pautada no tempo narrativo e na figura do narrador entre o conto de ficção científica "A história da sua vida" e sua adaptação cinematográfica, intitulada "A chegada". Após um breve percurso sobre o tempo e o narrador nas narrativas literária e cinematográfica, destacamos cinco pontos principais - sob o prisma da tradução intersemiótica - aqui resumidas nas perguntas de Culler “'quem fala?', 'quem fala para quem?', 'quem fala quando?', 'quem fala que linguagem?', 'quem fala com que autoridade?' e 'quem vê??,' (1999, p. 87-92).

Em relação a quem fala, no conto há a presença de uma narradora (Louise Banks), enquanto no filme há três - um narrador implícito na figura do diretor Dennis Villeneuve e dois explícitos nas figuras dos personagens Louise Banks e Ian Donnelley. No conto, a narradora fala ou para o leitor, ou para a sua filha, deixando a pergunta 'quem fala para quem?' não respondida, mantendo essa mesma dúvida na obra cinematográfica, apenas alterando a figura do leitor para a figura do espectador.

A terceira pergunta de Culler, quem fala quando, é respondida da mesma forma pelas duas obras com as peculiaridades reservadas a cada meio. No conto, é usado um sinal gráfico para determinar as mudanças entre presente e futuro/passado; no filme, são usados os tons de amarelo e azul. Por serem cores opostas, elas têm significados também opostos por si só e também no filme. Inicialmente, o amarelo representa a 
alegria enquanto o azul a tristeza e o luto. Porém, ao final do filme, percebe-se que o amarelo também representa um avanço no futuro/passado da narrativa presente que está em tom de azul.

Já as perguntas 'quem fala que linguagem?' e 'quem fala com que autoridade' parecem se restringir ao meio escrito, evocando o pensamento bakhtiniano acerca da polifonia (BAKHTIN, 2002, p. 82-83). A última pergunta, 'quem vê?', recebe respostas divergentes, já que a narradora do conto determina o ponto de vista da obra, ao passo que o narrador implícito ou grande imagista (JOST; GAUDREAULT, 2009, p.39) determina o foco do filme através da câmera (2009, p. 40-41) e seus enquadramentos, planos, ângulos e movimentações (MARTIN, 2005, p. 44). Além disso, a posterior montagem das cenas, igualmente determinadas pelo narrador implícito, é também sinal da sua presença na obra cinematográfica.

Compreende-se, então, que são três as perguntas respondidas de forma divergente, uma pergunta respondida de maneira convergente pelas obras analisadas e duas perguntas não são feitas na adaptação cinematográfica por questões referentes ao próprio gênero. Cabe também ressaltar que são mantidos três importantes efeitos de "A história da sua vida" em "A chegada", sendo eles: o momento da descoberta da temporalidade pelo receptor (a conversa de Louise Banks com o general); a circularidade do início e do fim das obras (na narrativa literária, há a repetição de frase, enquanto na narrativa cinematográfica, há a repetição de cena e de trilha sonora); e a menção ao número sete (são sete flashfoward/flashback na obra cinematográfica e sete membros e olhos dos heptapódes).

\section{Referências}

A CHEGADA. Direção de Denis Villeneuve. Estados Unidos: Sony Pictures, 2016. 1 DVD (116 min.).

ARISTÓTELES. Poética. 3. ed. Lisboa: Função Calouste Gulbenkian, 2008.

BAKHTIN, Mikhail. Questões de Literatura e Estética: A teoria do romance. 5. ed. São Paulo: Hucitec, 2002.

CHIANG, Ted. A História da sua vida e outros contos. Tradução de Edmundo Barreiros. 1a. ed. Rio de Janeiro: Intríseca, 2016. 
CULLER, Jonathan. Teoria literária: uma introdução. São Paulo: Beca, 1999, p. 84-94.

ECO, Umberto. Quase a mesma coisa: experiências de tradução. Tradução de Eliana Aguiar. 458 pp. São Paulo: Record, 2007.

GENETTE, Gérard. Figure III. Discorso del racconto. Torino: Einaudi, 1976.

JAKOBSON, Roman. Aspectos Lingüística e comunicação. São Paulo: Cultrix, 1975.

JOST, François; GAUDREAULT, André. A Narrativa Cinematografica. Brasília: Editora Universidade de Brasília, 2009.

METZ, Christian. A significação do cinema. São Paulo: Perspectiva, 2004.

MARTIN, Marcel. A linguagem cinematográfica. Lisboa: Dinalivro, 2005.

NOLETTO, Israel; LOPES, Sebastião. Heptapod B and the Metaphysics of Time Hybrid Interfaces of Literature, Cinema and Science. Polifonia, [S. l.], v. 25, n. 40.2, p. 206-221, 2018.

NUNES, Benedito. O tempo na narrativa. 2a. ed. São Paulo: Editora Ática, 1995.

OLIVEIRA, Guilherme Almeida. A ação das cores para o significado no audiovisual: um estudo do filme 'Her'. Monografia (Gradução em Publicidade e Propaganda). Centro Universitário Uniacademia, Juiz de Fora, 2020.

PLAZA, Julio. Tradução Intersemiótica. 1a. edição, $2^{\circ}$ reimpressão. São Paulo: Perspectiva, 2003.

PRAMAGGIORE, Maria; WALLIS, Tom. Film: a critic introduction. 2a. ed. Londres: Laurence King Publishing, 2008.

REUTER, Yves. A análise da narrativa: o texto, a ficção e a narração. Rio de Janeiro: DIFEL, 2002.

TODOROV, Tzvetan. "As categorias da narrativa literária." In: BARTHES, Roland. Análise estrutural da narrativa. Rio de Janeiro: Vozes, 2011 (1981), p. 218-264.

VAIANO, Bruno. Entenda a teoria linguística do filme "A Chegada". Galileu, 24/11/2016. Cultura. Disponível em $<$ https://revistagalileu.globo.com/Cultura/noticia/2016/11/entenda-teoria-linguistica-dofilme-chegada.html > Acesso em 18 jun. 2020.

ZAGO, Antonio. Numerologia: Mistérios do número sete. Revista Planeta. São Paulo: Editora Três, n. 84, setembro de 1979. 